\title{
RESEARCH ON THE CREATIVITY OF HIGH SCHOOL STUDENTS IN DA NANG CITY (TEST TCT-DP)
}

\author{
Giang Pham Thao, Thu Phan Nguyen Anh \\ Le Quy Don High School for the Gifted, Da Nang City, Vietnam \\ Email: thaogiang.research@gmail.com
}

\begin{abstract}
Context: Creativity is now said to be an important and top priority in education today. This is an important personality quality of a person expressed through thoughts and actions, especially ideas or products, solutions that a person gives to a problem, and creativity is the key factor to help one stand out or be different from others, it is even more important than intelligence or human potential. Anyone has the potential to be creative if they have the right understanding of creativity and are developed and honed in the right environment. However, traditional educational methods are causing limitations to students' creativity and it can be widely seen that the Creative Quotient (CQ) index in research papers on students is mostly average. Besides, the characteristics of today's new society along with the development of 4.0 technology, the expression of creativity in students has had certain changes compared to the studies of the past years.

Objective: The study was conducted on 222 students from 2 groups of gifted schools and non-gifted schools in Da Nang city, focusing on describing the current status of students' awareness about creativity and their creativity levels, learning about the expressions, components of creativity as well as analyzing the subjective and objective factors that affect creativity.

Methods: Research using questionnaire survey methods and in-depth interviews to survey the awareness on the creativity of high school students today, at the same time using creativity test TSD-Z (The Test for Creative Thinking - Drawing Production) to test students' creativity level, analyze the development ability and the correlation between the components of creativity with respect to factors such as grade, gender, group of gifted or non-gifted schools, thereby finding out the factors affecting creativity in high school students. Mathematical statistical methods using SPSS software were also used to process data and analyze results.

Results: In terms of awareness, students now have a basic knowledge of creativity's characteristics but still do not have a deep understanding of the components of creativity. In terms of creativity level, up to $57.4 \%$ of high school students are creative at an average level, about $9.3 \%$ of students are at a low level and $2.8 \%$ are at a high level according to the TSD-Z test. Factors such as gender, age, academic performance, behavior performance, or groups of gifted and non-gifted schools do not affect creativity and the components that make up creativity in high school students.

Conclusions: Thereby, from understanding the awareness's status of students; assessing the level of creativity and creative expression in students, the research team has conducted to develop appropriate measures to help improve students' understanding of creativity; Design creative enhancement programs in a variety of formats to help cover a wide range of audiences. At the same time, raising awareness and popularizing students' understanding of the knowledge they need to know related to creativity (such as the components that make up creativity) will be a theoretical method that contributes to improving students' creativity.
\end{abstract}

Keywords: Creativity, students, TSD-Z, TCT-DP, high school, Da Nang

\section{INTRODUCTION}

According to Alder (2002); Jensen et al (2010), creativity helps to orient students' future careers and is the basis for teachers to change teaching methods to suit each group of subjects, improving creativity for learners. In Vietnam, according to Tran Thi Bich Lieu (2016), teachers still have limited understanding and teaching about creativity. They focus more on creativity when it is required by policies and curricula and often use familiar and convenient creative tools.

Research by Nguyen Cong Khanh (2007) shows that $19.4 \%$ of students have low and very low CQ benchmarks, $49 \%$ are average; $24.1 \%$ above average and high to very high only accounted for $7.6 \%$. Le Thi Tuyet (2018) et al have research on students showing that $16.5 \%$ of students have a low level of creativity; $47.0 \%$ average; only $1.9 \%$ good and $0.7 \%$ excellent, saying that parents' stable careers, participation in cultural and extracurricular activities at school have an influence on creativity. Participating in the class officer helped to develop creativity by about 5 times. Duong Thi Anh Dao (2017) et al studied primary school subjects, using the 
TSD-Z method, showing $11.2 \%$ low levels; $43.1 \%$ average level; $14.7 \%$ average good; $11.6 \%$ good level; $8.7 \%$ excellent, and $6.3 \%$ excellent, but there was no difference in the rate of creativity between the sexes.

Research by Aranguren, M. (2012) shows that individuals who pursue artistic activities have a higher creative quotient than those who do not. Teresa M. Amabile et al (1986) examined the impact of rewards on the creativity of children and adults. Failure to receive a reward or just a surprise reward will not have the same negative impact on creativity as performing an activity to receive a reward. Tierney, P. (2011) claims that people who experience increased demand for creativity at work report a decrease in effectiveness for creative work.

Up to now, in the world, there are many definitions of creativity. According to Taylor, D.W. (1961), "create" - means to produce, to create something on the basis of an existing one or a newly formed one.

From the perspective of personality, K.Urban (1995) argues that creativity is a personality attribute that manifests in a product that works uniquely and optimally, surprising oneself and also being new to others. German psychologist Pippig (1988) defines creativity as a special personality attribute, which manifests when people are faced with problematic situations; it is a combination of psychological qualities by which people, on the basis of their experiences and by independent thinking, create new, original, and rational ideas on an individual or social level. There, the creators get rid of the traditional solutions and come up with a new, unique and appropriate solution to the problem posed. Le Nam Hai (2011) believes that creativity is a personality attribute that manifests through new and strange ideas and unique products that are not only valuable to individuals but also to society. According to Nguyen Duc Uy (1999), there is no distinction in creativity, whether more or less is all creativity.

Researching on the characteristics and expression of creativity, Guilford and Torrance (1979) and professor Pham Thanh Nghi (2012) stated that creativity is determined by a combination of the following characteristics and capabilities: (1 ) originality, (2) flexibility, (3) fluency, (4) elaboration and redefinition.

Studies at the Personality Institute of the University of California have come to the following conclusions:

1. Creative people excel in complexity in thinking;

2. The creator is more subtle and complex in the mind movement;

3. Creators are more independent in their evaluation;

4. Creative people have higher self-consciousness, higher self-confidence;

5. Creators are always against imposition and restriction.

Davis (1992) concluded that personality traits of creators include: (1) their sense of creativity, (2) originality, (3) independence, (4) risk-taking, (4) enthusiasm, (5) curiosity, (6) humor, (7) intrigued by complexity and novelty, (8) artistic sense, (9) openness, (10) need for privacy, (11) high perception.

From the perspective of process, Torrance (1962) defined creativity as an active process that ends in a unique new product that is recognized as useful by a certain group of people at a corresponding time. He supposed that "creativity is understood as a process of generating an idea or hypothesis, testing this idea or hypothesis then arriving at a result. The results obtained are more or less new, something that man had never seen before and had no consciousness of it." The author Watson (1928) said that creativity is viewed as a process of creating new things in human activities, creativity is evaluated on the basis of new, unique, and valuable products. Guilford (1967) considers creativity to be a problem-solving process because each problem-solving situation requires individual creative thinking. Faced with a problem, man mobilizes his experiences, combines them into a new structure, and with this new form of experience the problem is solved. In everyday life, around us, creativity is a necessary condition for existence, and everything that goes beyond the old framework and contains even a single feature of the new, its origin is due to the creative process of humans.

The creative process includes thinking analysis, comparison, synthesis, imagination, association, exploration, discovery, experimentation, and evaluation. Lucas et al (2012) decided that creative students will (1) Explore (2) Imagine (3) Specialize. Le Nam Hai (2011) said that creative people have many initiatives, have the ability to master different problems, they are sensitive to problems, and are unique in their way of solving problems.

From the perspective of the product, creativity is the product of new relationships among people, living backgrounds, and works of art. Ghiselin's (1956) definition of a creative product is the most widely accepted, according to which: "Creative product is the newest form of the world of experience, which best expresses the perception of the creative subject of the world and of himself as well as his relation to it". According to Guilford, there are two types of innovative products:

1. a specific perceptible creative product or a creative product recognized by a culture;

2. psychological products are not achieved by specific external activities, not necessarily perceived by the senses, but may be expressed ideas or exist only in the form of products of thought. 
Guildford argued that in the creative process, most thought products fall within the domain of divergent thinking, so they are called divergent products. Each factor in the Guilford model corresponds to certain capabilities as measured by the divergent product sum test (Divergence Productions - Test Batterie = DPT). These competencies are:

1. Fluency: is the ability to recall details and events accurately in the form of a) Words; b) ideas; c) Association;

d) Sentences or words.

2. Flexibility: the ability to transfer information memorized.

+ Spontaneous movement of information;

+ Adapting appropriate approaches to problem-solving;

3. Originality. In 1967, Guilford called it the Transformation Factor, that is, the willingness to see things differently first, expressed through:

$+\quad$ Rare and strange answers

+ Distant association

4. Create a new structure (Elaboration): the ability to create a new structure on the basis of the given information.

5. Sensitivity: the ability to recognize problems quickly, openness towards the surrounding environment.

6. Redefinition: the ability to interpret an object or part of a thing differently than before and use it for a completely new purpose.

Regarding the factors affecting creativity, creativity is also heavily influenced by socio-cultural factors such as education, parents' occupation, family economic conditions, and socio-cultural environment differences between urban and rural areas (Nguyen Cong Khanh, 2007). Research by Amabile (1983a, 1983b) and Do Thi Thanh Mai (2002) both confirmed that the environment affects students' creative motivation, that children in urban cities have higher creativity than their children in rural areas. Lubart \& Lautrey (1998) asserted that children from families with flexible rules tend to be more creative than children from families with rigid rules, regardless of economic level. Research by George, J.M (2007) suggested that the positive or negative mood of the members and the parent's educational style also affect the development of creativity. The stable occupation of parents also positively affects creativity (Le Thi Tuyet et al, 2018). Pham Thanh Nghi (2012) claims that parents of highly creative children, showing their closeness in dealing with their children, less domination or prohibition; meanwhile, parents' habits of behavior and answers when kids say they have a good idea also have an impact.

According to Pham Thanh Nghi, (2012), the general atmosphere of the open class is meant to encourage creativity. Research by Deci, Nezlek, and Sheinman (1981) and by Rosenthal, Baratz, \& Hall (1974) both show that the personality and behavior of teachers have an influence on students' creativity. The author's Le Thi Tuyet (2018) et al said that participating as a class officer helps to develop high creativity about 5 times. Sternberg (2010); Christina E. S.(2004), Amabile T. M. (2004) acknowledged the importance of activities, especially the participation in extracurricular activities. In the classroom, the lack of skills needed to be creative, lack of recognition, or isolation from the "basic" or core curriculum, can be a hindrance to creative thinking in math, science, and science. studies, languages, and social sciences (Shepard, 1988). Drews (1961) argues that organizing classes for students of the same level create better conditions for creativity than classes with students of different levels.

R.Keith Sawyer (2012) claims that more or less intelligence does not determine a person's level of creativity and the level of intelligence required for creativity is sometimes surprisingly low. Nguyen Cong Khanh (2007) concludes that the CQ index also has a relationship with the ability to work independently, the ability to adapt, the ability to self-study and research as well as the mastery of skills. Conti et al (1996) also believed that cognitive style, working style, and thinking ability also influence creativity. According to Bass M. et al (2008), creativity is most enhanced by active or positive mood states and is associated with approachable motivation and a motivating focus such as feelings of well-being.

Research by Amabile (1983a, 1996) and other scholars has pointed out the importance of motivation for creative work, arguing that it is difficult for people to do a creative job in their field unless they love doing it and focus on the work passionately due to the attraction of the object and the work content rather than because of the reward. Research by Torrance (1987) also shows that people who do things they enjoy are more creative when pursuing them.

Discussing measures to enhance creativity, Dan Rea (2003) argues that it is a need to influence education so that students learn to self-regulate their own motivation, educators need to support students to be aware of the 
measures to control their motivation and learn to control their own motivation. self-regulating way to reach the peak of optimal motivation for creative intelligence.

Amabile (1983a) Cropley (1992); Sternberg \& Lubart (1996) acknowledged the importance of developing creativity through training, creating an environment, and improving motivation. Haddon and Lytton (1968) propose to create a learning environment in which students can open and freely exchange ideas, encourage teamwork and discussion. and cooperation, prioritizing individual freedom. The home environment can provide cognitive (eg, intellectual stimulation) and affective (eg, emotional security) support for creativity (Harrington et al, 1987). Acceptance of creative ideas and creative individuals is also regarded as an important factor (MacKinnon, 1978). Developing creativity is possible through strengthening three elements of the new problemsolving structure: motivation, logical action, and intuitive action (Pham Thành Nghi, 2011a) which also encourages creativity every day, even small changes, but in the long run these small changes lead to big differences. The home environment can provide cognitive (eg, intellectual stimulation) and affective (eg, emotional security) support for creativity (Harrington et al, 1987).

Methods to enhance creativity can be mentioned as A. Osborn (1953) with Brainstorming Method used to activate creative ideas or Lateral Thinking by E.De Bono (1970), Synectics according to W. Gordon (1961), Creative Problem Solving by Guastella (1998), Herrmann Brain Dominance Instrument by N. Herrmann (1988), especially the Six Thinking Hats method of E. De Bono (1985).

In this article, we determine: the creativity of high school students is a quality, characteristic, and personality that is revealed through new, strange ideas and unique products in the life process (related to family, school, self...). At the same time, in this research, we will also find out about students' awareness of creativity, the components that make up creativity, and the status quo of creativity's level of high school students in DaNang City, as well as make a comparison between male and female.

\section{MATERIALS AND METHODS}

\section{Participants}

A sample of 222 students participated in the survey by completing an electronic questionnaire comprising 69 male students and 153 female students. These students were selected evenly from 2 groups of schools which are gifted and non-gifted schools (above seven schools in the city) and three grade levels which are grades ten, eleven, and twelve.

Overview of gifted school

Gifted School: Gifted students demonstrate a high degree of intellectual ability. Typically, identification can be done through a combination of gifted tests and assessments. In many cases, tests are used to determine whether a child is gifted or not since performance compared to peers is an important way of gauging a child's academic abilities.

\section{Measure}

Measure the awareness of students about creativity

Participants who agreed to participate signed informed consent and then completed the questionnaire. We developed a questionnaire consisting of 5 question groups, including:

1. Question group 1: awareness of students about creativity (importance, forms expressing, factors affecting, components)

2. Question group 2: current status of creativity educational for students (at home and at school);

3. Question group 3: proposed measures to develop creativity

4. Question group 4: expressions of creativity in students with 21 items, using a scale of 1 to 5 points

- $1=$ completely incorrect;

- 2 = hardly true;

- 3 = moderate;

- $4=$ almost true

- 5 = completely correct

5. Question group 5: Students' general information: Gender, grade level, school, academic performance, behavior performance, hobby and aptitude...).

Measure the creativity level of students 
The TSD-Z test has only one page on which a number of textures are given that stimulate the subject's freedom to continue drawing. The test asks the subject to redraw a complete picture with 6 available strokes called 6 textures. The participants also wrote the necessary information in the section on the test page such as: Full name, gender, class, school, time of testing, and the subject of the picture. Drawing products will then be evaluated on 14 criteria with a maximum total score of 72 points. The total maximum score in a TSD-Z test is 72 points.
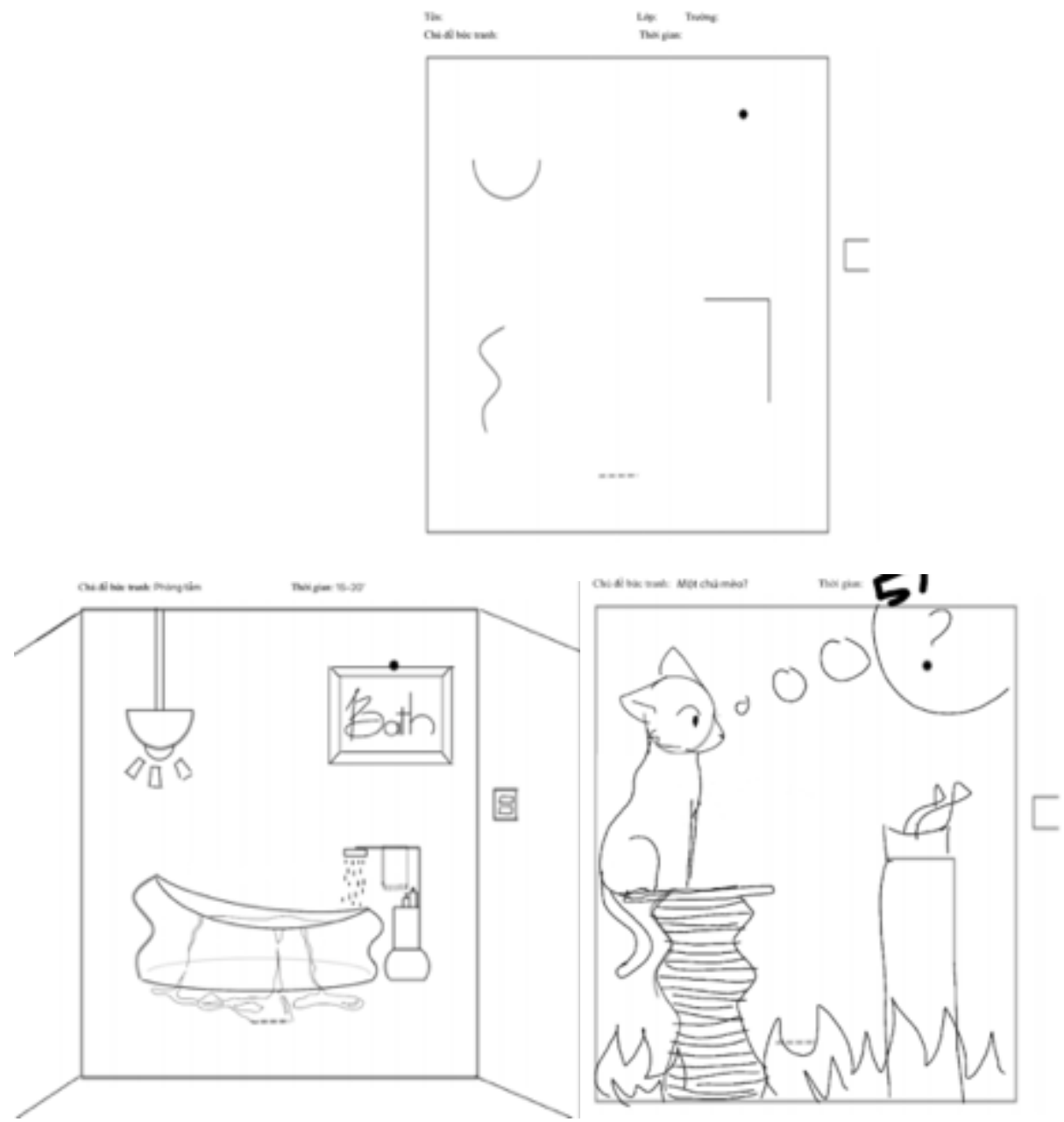

Figural production is evaluated according to 14 evaluation criteria which represent the present test construct:

- Use of presented fragments (Wf) - at most 6 points

- $\quad$ Sketching $(\mathrm{Eg})$ - at most 6 points

- New elements $(\mathrm{Ne})$ - at most 6 points

- Graphic connection (Vz) - at most 6 points

- Thematic connection (Vth) - at most 6 points

- The border exceeding dependent on a figure (Bfa) $-0 ; 3$ or 6 points

- The border exceeding not dependent the figure (Bfu) $-0 ; 3$ or 6 points

- Perspective $(\mathrm{Pe})-0$ or 6 points

- Humour, effectiveness, emotionality, expressive power of drawing (Hu) - at most 6 points -

- Unconventionality A (manipulation with material) + B (abstraction, surrealistic topic) + C (use of signs and symbols) $+\mathrm{D}$ (not using of stereotype figures) - for each factor 0 or 6 points

- $\quad$ Time factor $(\mathrm{Zf})$ - at most 6 points.

Table of distribution of students' creativity levels according to TSD-Z Urban.

\begin{tabular}{|c|c|c|c|c|c|c|c|}
\hline Level & $\begin{array}{c}\text { A } \\
\text { Poor }\end{array}$ & $\begin{array}{c}\text { B } \\
\text { Low }\end{array}$ & $\begin{array}{c}\text { C } \\
\text { Average }\end{array}$ & $\begin{array}{c}\text { D } \\
\text { Above average }\end{array}$ & $\begin{array}{c}\text { E } \\
\text { High }\end{array}$ & $\begin{array}{c}\text { F } \\
\text { Very good }\end{array}$ & $\begin{array}{c}\text { G } \\
\text { Excellent }\end{array}$ \\
\hline
\end{tabular}


The table specifies the score according to each component of students' creativity levels according to TSD-Z Urban.

\begin{tabular}{|l|l|l|}
\hline \multicolumn{1}{|c|}{ Component } & \multicolumn{1}{|c|}{ Criteria } & \multicolumn{1}{|c|}{ Maximum point } \\
\hline Flexibility & Vth, Eg, Pe & 18 points \\
\hline Originality & Ukb, Ukc, Ukd & 9 points \\
\hline Fluency & Bfu, Vz & 12 points \\
\hline Redefinition & Ne, Uka, Bfa, Hu & 27 points \\
\hline Elaboration & Wf, Zf & 12 points \\
\hline
\end{tabular}

\section{Analysis}

Mathematical statistical methods: The Statistical Package for the Social Sciences (SPSS) version 22.0 was used for data analyses. We use SPSS 22.0 software to analyze mean score data; ratio \%; standard deviation, the correlation between groups,... The coding procedure was performed as followed:

- $0=$ do not agree

- 1 = agree

\section{RESULTS AND DISCUSSION}

Table 1. Student's awareness relating to components of creativity and factors influencing

s

\section{Essential elements of a creative idea}

$\begin{array}{ccccc}\text { Originality } & \text { Male } & .942 & .2354 & 1 \\ & \text { Female } & .916 & .2789 & \\ \text { Flexibility } & \text { Male } & .435 & .4994 & 6 \\ & \text { Female } & .422 & .4955 & \\ \text { Fluency } & \text { Male } & .580 & .4972 & 5 \\ \text { Novelty } & \text { Female } & .519 & .5013 & \\ & \text { Male } & .826 & .3818 & 2 \\ \text { Practical applicability } & \text { Female } & .838 & .3700 & \\ & \text { Male } & .623 & .4881 & 3 \\ \text { Developing on the old things } & \text { Female } & .597 & .4920 & \\ \text { Having public's recognition } & \text { Male } & .594 & .4946 & \\ & \text { Female } & .539 & .5001 & \\ & \text { Male } & .290 & .4570 & \end{array}$




\begin{tabular}{ccccc} 
& Female & .201 & .4023 \\
Having big impact and causing an immediate change & Male & .435 & .4994 & 7 \\
& Female & .351 & .4787 & \\
\hline Total & & & & \\
\hline & Male & 5.884 & 2.2657 \\
& Female & 6.351 & 2.1191 \\
\hline
\end{tabular}

\section{Factors that influence creativity}

\begin{tabular}{|c|c|c|c|c|}
\hline \multirow{2}{*}{ Family care for children } & Male & .435 & .4994 & \multirow{2}{*}{7} \\
\hline & Female & .370 & .4844 & \\
\hline \multirow{2}{*}{ How parents deal with situations } & Male & .551 & .5011 & \multirow{2}{*}{6} \\
\hline & Female & .500 & .5016 & \\
\hline \multirow{2}{*}{ How teachers teach in schools } & Male & .681 & .4694 & \multirow{2}{*}{4} \\
\hline & Female & .669 & .4722 & \\
\hline \multirow{2}{*}{$\begin{array}{l}\text { The relationship between teachers and students in the } \\
\text { school }\end{array}$} & Male & .188 & .3939 & \multirow{2}{*}{10} \\
\hline & Female & .143 & .3511 & \\
\hline \multirow{2}{*}{ Persistence towards the goal } & Male & .667 & .4749 & \multirow{2}{*}{5} \\
\hline & Female & .662 & .4745 & \\
\hline \multirow{2}{*}{ Enthusiasm and interest in an issue } & Male & .942 & .2354 & \multirow{2}{*}{1} \\
\hline & Female & .935 & .2472 & \\
\hline \multirow{2}{*}{ The initiative towards work naturally } & Male & .797 & .4051 & \multirow{2}{*}{3} \\
\hline & Female & .773 & .4204 & \\
\hline \multirow{2}{*}{ Motivation and desire to develop creativity } & Male & .797 & .4051 & \multirow{2}{*}{2} \\
\hline & Female & .786 & .4117 & \\
\hline \multirow{2}{*}{ Reward or punishment for doing something } & Male & .406 & .4946 & \multirow{2}{*}{8} \\
\hline & Female & .305 & .4620 & \\
\hline \multirow{2}{*}{ Peer pressure } & Male & .275 & .4500 & \multirow{2}{*}{9} \\
\hline & Female & .182 & .3870 & \\
\hline \multicolumn{5}{|l|}{ Total } \\
\hline & Male & 3.841 & 1.2558 & \\
\hline & Female & 4.247 & 1.2436 & \\
\hline
\end{tabular}

S: Sex; M: Mean; SD: Standard Deviation; R: Ranking.

Students are well acknowledge than that orginality (which has $\mathrm{M}=0.942$ in male and $\mathrm{M}=0.916$ in females) and noveare well acknowledgednts of creaoriginalityese are the two highest-ranmalesfactors. However, apart from the above two factors, students are completely confused about the essential elements of a creative product. Besides, there are 2 factors "Having public's recognition" with and "Having big impact and causing an immediate change" which are the two confounding public also ranked lowest, meanwhile there is still a number of students choosing, which means that there is still a misunderstanding among students about creativity. In terms of the difference 
between males and females, it is found that there is no obvious difference in perception between men and women with sig. greater than 0.05 .

Regarding students' awareness of the factors affecting creativity, the most important factor is "Enthusiasm and interest in an issue" with $\mathrm{M}=0.942$ in males and $\mathrm{M}=0.935$ in females. In second place is the element "Motivation and desire to develop creativity". Similar to the results on the perception of the characteristics of creativity, in this part, students also recognized two main confounding factors, "The relationship between teachers and students in the school" and "Peer pressure". After deep analysis, with sig. greater than 0.05 indicates no difference in the perception of factors affecting creativity in both sexes.

Thereby, when comparing with previous research results in Vietnam and the world on influencing factors, it can be seen that students' perceptions are relatively correct, they have a basic knowledge of creativity and students know what will affect their creativity through their own experiences and perspectives. At the same time, high school students have grasped the elements of creativity, but still do not have a deep understanding of the elements of creativity. A student, N.V.H, from Le Quy Don high school for the gifted shared his thoughts "In my opinion, novelty means both "new" and "unique", not repeating boring, dry things, interesting, unique, easy to absorb, easy to associate, easy to apply. Those are the points that a person or something I consider creative must-have, and they also really attract me the most." L.T.M.K, a student from Phan Chau Trinh high school supposed that "I often push myself to be creative and try to be stand out in projects or jobs that I'm interested in and really passionate about, the other things that I do not like I just do normally, whatsoever". Importantly, there is no difference in perception between males and females.

Table 2. Creativity level of high school students in Da Nang City in terms of gender, grade, and school according to TSD-Z Test

\begin{tabular}{|c|c|c|c|c|c|c|c|c|c|c|}
\hline & & & & & & Level & & & & \\
\hline & & & $\begin{array}{c}\text { A } \\
\text { Poor }\end{array}$ & $\begin{array}{c}\text { B } \\
\text { Low }\end{array}$ & $\begin{array}{c}\text { C } \\
\text { Average }\end{array}$ & $\begin{array}{c}\text { D } \\
\text { Above } \\
\text { average }\end{array}$ & $\begin{array}{c}E \\
\text { High }\end{array}$ & $\begin{array}{c}\text { F } \\
\text { Very good }\end{array}$ & $\begin{array}{c}\text { G } \\
\text { Excellent }\end{array}$ & Total \\
\hline Grade & $\begin{array}{c}\text { Grade } \\
10\end{array}$ & $\mathrm{n}$ & 0 & 3 & 7 & 3 & 3 & 0 & 0 & 16 \\
\hline & & $\%$ & 0 & 18,75 & 43,75 & 18,75 & 18,75 & 0 & 0 & 100 \\
\hline & $\begin{array}{c}\text { Grade } \\
11\end{array}$ & $\mathrm{n}$ & 1 & 3 & 19 & 12 & 2 & 0 & 0 & 37 \\
\hline & & $\%$ & 2,7 & 18,75 & 51,35 & 32,43 & 5,41 & 0 & 0 & 100 \\
\hline & $\begin{array}{c}\text { Grade } \\
12\end{array}$ & $\bar{n}$ & 0 & 4 & 36 & 10 & 2 & 3 & 0 & 55 \\
\hline & & $\%$ & 0 & 7,27 & 65,45 & 18,18 & 3,64 & 5,45 & 0 & 0 \\
\hline Gender & Male & $\mathrm{n}$ & 1 & 2 & 16 & 10 & 2 & 0 & 0 & 31 \\
\hline
\end{tabular}




\begin{tabular}{|c|c|c|c|c|c|c|c|c|c|c|}
\hline & & $\%$ & 3,23 & 6,45 & 51,61 & 32,26 & 6,45 & 0 & 0 & 100 \\
\hline & \multirow[t]{2}{*}{ Female } & $\mathrm{n}$ & 0 & 8 & 46 & 15 & 5 & 3 & 0 & 77 \\
\hline & & $\%$ & 0 & 10,39 & 59,74 & 19,48 & 6,49 & 3,9 & 0 & 100 \\
\hline \multirow[t]{4}{*}{ School } & \multirow[t]{2}{*}{$\begin{array}{l}\text { Gifted } \\
\text { High } \\
\text { School }\end{array}$} & $\mathrm{n}$ & 1 & 4 & 38 & 15 & 1 & 3 & 0 & 62 \\
\hline & & $\%$ & 1,61 & 6,45 & 61,29 & 24,19 & 1,61 & 4,84 & 0 & 100 \\
\hline & \multirow[t]{2}{*}{$\begin{array}{c}\text { Non-gifted } \\
\text { High } \\
\text { School }\end{array}$} & $\mathrm{n}$ & 0 & 6 & 24 & 10 & 6 & 0 & 0 & 46 \\
\hline & & $\%$ & 0 & 13,04 & 52,17 & 21,74 & 13,04 & 0 & 0 & 100 \\
\hline
\end{tabular}

n: Number of participants; \%: Percentage

In terms of gender, specifically, in both males and females, the highest proportion is still the average level, in which male is $51.61 \%$ and female is $59.74 \%$. Next, the second-highest rate is still the good level, in which the male rate is higher than that of females when it is $32.26 \%$ for males and $19.48 \%$ for females. The remaining levels account for a relatively small proportion and are scattered.

The results of the T-Test for genders and creativity levels showed that there was no statistically significant difference in the creativity level of students of different genders ( $\mathrm{p}=0.94>0.05)$

In terms of grade, creativity at the average level accounted for the highest rate in all 3 grades, in which the rate of 12 th grade was higher than that of the other 2 grades, from 10th to 12 th grade was $43.75 \% 51.35 \%$, and $64.45 \%$. respectively. The second highest rate is above average and this ratio is true for all 3 grades. Grade 10 is evenly distributed at low, above average, and good levels with $18.75 \%$ at each level, there are no students at low and high levels. For grade 11 there are $2.7 \%$ at a poor level. Grade 12 has $5.45 \%$ high creativity and no students at a low level.

The Anova test was used to analyze the relationship between creativity and, which showed that there is no significant difference in the grade levels $(\mathrm{p}=0.948>0.05)$

In terms of school, it is clearly visible that the two factors with the highest percentage are the average and above-average levels respectively. In gifted school, more than half of the students, or about $64.41 \%$ of the students, were average and $25.42 \%$ above average. As for other non-gifted high schools, the rate is similar but slightly less, with $52.17 \%$ and $24.74 \%$ at average and above-average levels, respectively. Next in both groups of schools is low level with $6.78 \%$ in gifted schools and $13.04 \%$ in non-gifted schools. In gifted schools, there is still a percentage of students who achieve low and high scores.

The results of the T-Test for school and creativity levels showed that there is no statistically significant difference in the level of creativity of students in 2 groups of gifted and non-gifted schools $(p=0.687>0.05)$

Table 3. The average score of creativity between two sexes

Gender Score Level




\begin{tabular}{ccc}
\hline Male & $33.29 / 72$ & Average \\
Female & $33.81 / 72$ & Average \\
\hline
\end{tabular}

From the table above, it can be seen that in the TSD-Z drawing test, both men and women reached the average level. Males have a score of 33.29 and females were 33.81 (women still scored more than 0.2 points higher than men). Although there was a difference in the TSD-Z tests, the difference was not significant.

Besides, according to the Independent Samples T-Test method, we get sig. $=0.216(>0.05)$. That shows that there is no difference in the level of creativity in both tests in gender.

Table 4. Average components score of creativity between two sexes

\begin{tabular}{|c|c|c|c|c|c|c|}
\hline & & $\begin{array}{l}\text { Flexibility } \\
(\max 18)\end{array}$ & $\begin{array}{l}\text { Originality } \\
(\max 9)\end{array}$ & $\begin{array}{l}\text { Fluency } \\
(\max 12)\end{array}$ & $\begin{array}{l}\text { Redefinition } \\
\quad(\max 27)\end{array}$ & $\begin{array}{l}\text { Elaboration } \\
(\max 12)\end{array}$ \\
\hline \multicolumn{7}{|l|}{ Male } \\
\hline & $\mathrm{M}$ & 12.065 & 3.903 & 2.903 & 7.903 & 6.516 \\
\hline & $\mathrm{n}$ & 31 & 31 & 31 & 31 & 31 \\
\hline & SD & 2.6196 & 2.0225 & 2.9366 & 3.8846 & 2.5281 \\
\hline \multicolumn{7}{|c|}{ Female } \\
\hline & $\mathrm{M}$ & 12.234 & 3.299 & 3.182 & 8.481 & 6.286 \\
\hline & $\mathrm{n}$ & 77 & 77 & 77 & 77 & 77 \\
\hline & $\mathrm{SD}$ & 2.9060 & 1.9872 & 3.1860 & 4.4592 & 1.9116 \\
\hline \multicolumn{7}{|l|}{ Total } \\
\hline & $\mathrm{M}$ & 12.185 & 3.472 & 3.102 & 8.315 & 6.352 \\
\hline & $\mathrm{n}$ & 108 & 108 & 108 & 108 & 108 \\
\hline & $\mathrm{SD}$ & 2.8157 & 2.1968 & 3.1054 & 4.2922 & 2.0972 \\
\hline
\end{tabular}

M: Mean; SD: Standard Deviation; n: number of participants

From the table above, it can be seen that in both sexes, ranked first is "flexibility" which has an average score that is much better than the rest, average score of men and women are 12,065 and 12,234 respectively above average of maximum score.

Next in both sexes are followed by "redefinition" and "elaboration", while in "redefinition", women have a higher average score than men ( $M=8,481$ as for females and $M=7,903$ as for males). then in "elaboration" men have a higher average score which is 6,516 than women with a score of 6,286 . The two components with the lowest rankings of both sexes are "originality" and "fluency". As for "originality", men (average score is 3.903) higher than women with a score of 3.299. The comparison is different when come to "fluency" - a component 
with lowest ranking, the average score in male being 2.903 and female being 3.182. It can be seen that in some components women are superior to men, and in some components, the opposite is true, however, that difference is not too much, which means that there are still differences in the components that make up creativity, but in general, they are still equivalent and do not affect the overall level of creativity in both sexes.

In short we find that, a majority of students are quite good at "flexibility", which is the ability to the ability to transform information received and quickly transfer it from this perspective of view to perspective, as well as the ability to redefine things in a whole new way. "Originality" and "fluency" of student's just occupied one third of maximum score, which means they still need a lot of improvements in the ability to think far into the unthinkable as well as show a surprising difference in the choice of implementation of ideas from common everyday solutions (originality) in addition to the ability to combine individual elements of a situation as well as the ability to associate known ideas stored in memory in order to combine individual elements of things into a complete meaningful picture (fluency).

\section{CONCLUSION}

Students now have a basic awareness of the characteristics or elements of creativity but still do not have a deep understanding of the components of creativity. The relationship analysis shows that if students perceive and understand the components of creativity, they will know how to improve their own creativity based on those constituent componens. Therefore, raising awareness and popularizing students' understanding of the knowledge they need to know related to creativity will be a theoretical method that contributes to improving students' creativity. Students at the same time perceive and evaluate the influencing factors from themselves, from family, education to their own creativity. When comparing between men and women, there was no significant difference in perception between the two sexes.

In terms of creativity, up to $57.4 \%$ of high school students are creative at an average level, about $9.3 \%$ of students are at a low level and $2.8 \%$ at a high level according to Test TSD- Z. There is no difference in the level of creativity in both tests in gender. Regarding the components of creativity, the majority of high school students almost achieve a good level in "flexibility" component while they are quite weak and need an improvement in "originality" and "fluency". Factors such as gender, age, academic ability, behavior, or groups of gifted and non-gifted schools do not affect creativity and the components that make up creativity in high school students.

\section{REFERENCES}

1. Alder H. (2002). CQ: Boost Your Creative Intelligence: Powerful Ways to Improve Your Creativity Quotient. Kogan page, London, 12-28.

2. Jensen J. Zhao, Sherry Y. Zhao (2010). The Impact of IQ+EQ+CQ Integration on Student Productivity in Web Design and Development. Journal of Information Systems Education, 21(1), 43-53.

3. Tran Thi Bich Lieu (2017), Assessment of knowledge, competence and creativity: Differences and similarities, Hanoi National University of Education

4. Nguyen Cong Khanh (2007), Summary report on research results of student's creativity index, Vietnam National University, Hanoi, VNU, Hanoi.

5. Le Thi Tuyet, Nguyen Dieu Linh (2018), "Creativity index of students in the biology department of Hanoi National University of Education and some related factors", Faculty of Biology, Hanoi National University of Education, HNUE Journal of Science, Natural Sciences 2018, 63(3), 158-166.

6. Duong Thi Anh Dao and Le Thi Tuyet (2017), Actual situation of creativity index of students at Doi Can Primary School, Thai Nguyen city and the relationship between some environmental factors in the family and creativity index children, Department of Biology, Hanoi National University of Education, Natural Sci., 62(3), 121-126

7. Aranguren, M. \& Irrazabal, N. (2012). A scale for the evaluation of Creativity Behavior in different domains: Development and design. Ciencias Psicológicas, 6(1), 29-41 as cited in Agustín FreibergHoffmann, Carlos Vigh, and Mercedes Fernández-Liporace (Eds), "Creative Personality Scale. A new version for college students from Argentina", Annals of psychology 2019, 35(2), 290-299 
8. Teresa M. Amabile, Beth Ann Hennessey, and Barbara S. Grossman (1986) Social Influences on Creativity: The Effects of Contracted-for Reward. Journal of Personality and Social Psychology, 50(1), 14-23

9. Tierney, P., \& Farmer, S. M. (2011). Creative self-efficacy development and creative performance over time. Journal of Applied Psychology, 96(2), 277-293.

10. Taylor, D.W (1961), "Environment and Creativity”. In: Conference on the Creative Person. Uni. Calif. Institute of Personality Assessment and Research, Berkely.

11. Urban, K.K., \& Jellen, H.G. (1985). Der TSD-Z: Test zum schöpferischen Denken - zeichnerisch. Universität Hannover, Arbeitsstelle HEFE, Paper 6 as cited in Klaus K. Urban (2004), Assessing Creativity: The Test for Creative Thinking - Drawing Production (TCT-DP) The Concept, Application, Evaluation, and International Studies, Psychology Science 46(3), 387 - 397

12. Pippig, G (1988). "Pädagogische Psychologie". Volk und Wissen, Volkseigener Verlag, Berlin.

13. Le Nam Hai, Ha Thi Hoai Huong (2011), Creative research from the point of view of Personality, Journal of Science, Hue University, 68, 2011

14. Nguyen Duc Uy (1999), Creative Psychology, Education Publishing House, Hanoi.

15. Pham Thanh Nghi (2012), Creative Psychology Textbook, Hanoi National University Press

16. Torrance, E. P. (1962). Guiding creative talent. Prentice Hall, Inc

17. Watson, J. (1928). Behaviorism. London: Kegan Paul.

18. Guildford, J.P. (1967) “Intellectual factors in productive thinking”. In: Explorations in Creativity. New York.

19. Bill Lucas, Guy Claxton and Ellen Spencer (2012), Progression in Creativity: Developing new forms of assessment, Centre for Real-World Learning, The University of Winchester, England

20. Ghiselin, B (1956). "The creative process and its relation to the identification of creative talent". Salt Lake City.

21. Amabile, T. M. (1983a) The Social Psychology of Creativity: A Componential Conceptualization. Journal of Personality and Social Psychology, 45(2), 357-376

22. Do Thi Thanh Mai (2000), Research on the creative ability of preschool children aged 5-6 years old through drawing activities, Master's Thesis

23. Lubart, T., \& Guignard, J.-H. (2004). The Generality-Specificity of Creativity: A Multivariate Approach. In R. J. Sternberg, E. L. Grigorenko, \& J. L. Singer (Eds.), Creativity: From potential to realization, American Psychological Association, 43-56

24. George, J.M. (2007). Creativity in organizations. Academy of Management Annals, 1(1), 439-477.

25. Deci, E.L., Nezlek, J., \& Sheiman, L. (1981). Characteristics of the rewarder and intrinsic motivation of the rewardee. Journal of personality and social Psychology, 40.

26. Sternberg, R. J. (2010). Teaching for creativity. In R. A. Beghetto \& J. C. Kaufman (Eds.), Nurturing creativity in the classroom, 394-414. Cambridge University Press

27. Christina E. Shalley, Jing Zhou and Greg R. Oldham, (2004). The Effects of Personal and Contextual Characteristics on Creativity: Where Should We Go from Here? Journal of Management, 30, p. 933958

28. Amabile T. M., Schatzel E., Moneta G., and Kramer S., (2004). Leader behaviors and the work environment for creativity: Perceived leader support. Leadership Quarterly, 15(1), p. 5-32.

29. R.Keith Sawyer (2012), Explaining Creativity: The Science of Human Innovation, Oxford University Press, Second Edition.

30. Drews, Elizabeth M., (1961), A Critical Evaluation of Approaches to the Identification of Gifted Students

31. R.Keith Sawyer (2012), Explaining Creativity: The Science of Human Innovation, Oxford University Press, Second Edition.

32. Amabile, T.M., Conti, R., Coon, H., et al. (1996) Assessing the Work Environment for Creativity. Academy of Management Journal, 39 In Emanuel Jauk, Lisa Eberhardt, Corinna Koschmieder, Jennifer Diedrich, Jürgen Pretsch, Mathias

33. Benedek \& Aljoscha C. Neubauer (2019) (Eds), A New Measure for the Assessment of Appreciation for Creative Personality, Creativity Research Journal, 31(2), 149-163 
34. Torrance, E. P. (1987).Future Career Image as a Predictor of Creative Achievement in a 22-Year Longitudinal Study. Psychological Reports. 60(2), 574.

35. Rea, D. (2003). Optimal Motivation for Creative Intelligence. Creative Intelligence: Toward Theoretic Integration, Chapter 9, 211-235.

36. Cropley, A. J. (1992). More ways than one: Fostering creativity. Norwood, NJ: Ablex Publishin Corporation.

37. Sternberg, R. J., \& Lubart, T. I. (1996). Investing in creativity 51(7), 677-688.

38. Haddon, F. A., \& Lytton, H. (1968). Teaching approach and the development of divergent thinking abilities in primary schools. British Journal of Educational Psychology, 38(2).

39. Harrington, D. M., Block, J. H., \& Block, J. (1987). Testing aspects of Carl Rogers's theory of creative environments:

40. Child-rearing antecedents of creative potential in young adolescents. Journal of Personality and Social Psychology, 52, 851- 856.

41. MacKinnon, D. W. (1978). In search of human effectiveness: Identifying and developing creativity. Buffalo: Creative Education Foundation. In Emanuel Jauk, Lisa Eberhardt, Corinna Koschmieder, Jennifer Diedrich, Jürgen Pretsch, Mathias

42. Benedek \& Aljoscha C. Neubauer (2019) (Eds), A New Measure for the Assessment of Appreciation for Creative Personality, Creativity Research Journal, 31(2), 149-163

43. Phạm Thành Nghị (2011a). Phát triển tư duy sáng tạo thông qua hoạt động giải quyết vấn đề mới”, Tạp chí Khoa học Giáo dục, 68, 9-13.

44. Osborn, A.F., 1953 (rev. 1957, 1963), Applied Imagination: Principles and Procedures of Creative Problem-Solving, New York.

45. De Bono, E. (1970). Lateral Thinking: Creativity Step by Step. New York: Harper \& Row.

46. Gordon, W. J. J. (1961). Synectics: The development of creative capacity. Harper.

47. Guastello, Stephen J. (1988), Creative Problem Solving Groups at the Edge of Chaos, Journal of Creative Behavior, 32(1), 38-57

48. Herrmann, N. (1988). The Creative Brain. Lake Lure, North Carolina: Brain Books

49. De Bono, E. (1985). Six Thinking Hats. London: Penguin Books. 